\title{
A response to human affliction and social loss
}

\author{
Hélène Jaffe Head of the Health Centre AVRE (Association for Victims of Repression in Exile), Paris, France
}

There is today a growing awareness both of the prevalence of torture - involving a very large number of countries around the world - and of the depth of the human suffering it leaves in its wake. Individual lives have been broken, the stability of families shattered, the psychic equilibrium of the children of torture victims disrupted. In the words of Simone Veil, former President of the European Parliament and herself an internee of the Auschwitz concentration camp: 'It is not only the rights of the victims which are scorned, it is not only their lives which are threatened, it is the very essence of these human beings that torture seeks to annihilate'.

The Association for Victims of Repression in Exile (AVRE), among the first of such groups to be set up, was founded in Paris in 1984, and is housed on the premises of the Hôpital de la Croix Saint-Simon. The fact that France has traditionally been a major country of refuge lends particular significance to the association's location in Paris.

AVRE's primary on-going activity is as a centre that caters to the medical and psychological needs of persons seeking aid because they have suffered torture or other forms of ill-treatment in their countries of provenance; it also increasingly offers assistance to victims' families. Nearly a thousand people had been cared for at the Paris centre by 1990 .

All patients come to us on the basis of referral - by humanitarian bodies, as well as by hospitals, doctors, lawyers and refugee associations. At present, more than five per cent of new arrivals are non-refugees who have been helped by human rights organisations to come to France for treatment subsequent to their release from prison.

A second dimension of AVRE's activity consists of missions abroad to extend, in situ, where this is possible and desirable, the particular kind of aid which may be called for. One example is the establishment of a sustained programme of care provided in former French Guinea, in 1984-1985, to political prisoners freed after the death of Sekou Touré. AVRE fulfilled a very different type of need when a fact-finding team briefly visited The Philippines to ascertain the help required from abroad in caring for prisoners liberated upon the departure of President Marcos.

Other missions have included on-the-spot treatment, given in co-operation with local doctors, to newly released Moroccan political internees and an inquiry, in 1988, into the phenomenon of torture in the political and social context of Zaïre.

The 'why' of AVRE's existence cannot be answered fully without giving due weight to its role in the international effort to bring together, analyse and compare knowledge and experience acquired in the treatment of torture victims and in activities related to torture. Hence, the association's close co-operation with similar groups in other countries and its frequent participation in international symposia dealing with the specific problems faced by practitioners in this field, or with the issues to which torture gives rise in ac broader medical and psychiatric framework.

This international dimension of the association's work also encompasses co-operative research ventures, as exemplified by AVRE's membership in ALFEST (the French-Language Association for the Study of Traumatic Stress), its participation in the European Concerted Action for coping with Disasters (EuroActDis), work on the prevention of mass reactions to natural and other disasters and its involvement in an international research project on the sequelae of violence in children.

AVRE has been encouraged in the pursuit of its mission by the growing support it has received from leading figures in science, the arts and public affairs.

\section{The people cared for}

\section{SHIFTING GEOGRAPHICAL AND SOCIOLOGICAL} PATTERNS

AVRE deals with human problems, in an individual or family context - often the two are combined. It does not concern itself with the political leanings of its patients or with the ideology of the regimes which have subjected them to the inhuman treatment from which they are suffering. The effects of torture are blind to politics: they take their toll on ideologically undifferentiated human bodies and minds.

Nevertheless, there has been a striking alteration over the years in the pattern of geographical provenance of AVRE's patients. The factors behind this shift include, of course, the evolution of world politics and changes in various circumstances which may draw torture victims to France. But it is important 
to mention, in this context, our growing awareness of the attempts made by some persons to use AVRE as a springboard for the acquisition of refugee status and the association's determination not to lend itself to this practice.

While over three-quarters of the patients received in 1985 came from tropical Africa, that region accounted for only about one-third of those being treated in 1990 . A development in the opposite direction has been observed with respect to patients from Asia. Constituting only a modest proportion of the total in 1985, Asians - in particular Tamils, Pakistanis and people from Bangladesh and Southeast Asia - now comprise the largest contingent. The Latin American element has remained quite small, and the number of persons from Eastern Europe has declined because of the recent political developments in that area.

Clearly, these shifts in geographic distribution have put a premium on AVRE's capacity to familiarise itself with social and political backgrounds imperfectly understood in Europe. A comparable need for adjustment has arisen from the greater emphasis accorded to the treatment of women and children, bringing into play the frequently traumatic relationships between those who have 'stayed at home' in conditions of constant apprehension and uncertainty and the returned head of family who may have undergone a severe alteration in his personality structure.

This 'traumatised relationship' is only one manifestation of the complex and far-reaching effects of torture on the family.

The discovery of such effects and their exploration, present AVRE's staff with a permanent double challenge: to augment its knowledge of the multiple ramifications of torture, and to deepen its understanding of the ways in which they may be remedied.

\section{Silence: a barrier that must be destroyed to permit healing}

The aim of AVRE is to heal those damaged by torture so as to enable them to become full human beings once more and to lead a viable existence by learning to cope with the often tenacious sequelae of their ordeal.

In order to heal, it is first necessary to break down the wall of silence that surrounds the victims. Torture reduces these people to silence by the way it congeals their psyches as well as by the torturer's injunctions: 'If you talk afterwards, we'll begin again ...'. The healing process cannot set in until this barrier begins to crumble.

Torture also constrains societies to silence. This is true of the societies where it is perpetrated, which are petrified by fear and by the persistent harassments that must be faced in the daily struggle for survival. Our own societies' indifference to torture results in a silence which reflects badly on us and does a disservice to those who are suffering.

Thus a key element in the work of AVRE is the effort to unfreeze the channels of communication with the victims of torture, by approaches developed over years of experience, and to sensitise others to the effects, and gravity, of torture as a 'sickness of society' which cannot be tolerated.

\section{A holistic therapy is needed to treat the multiple wounds inflicted by torture}

Torture is a polytraumatic phenomenon. It attacks the physical, mental, emotional and social integrity of the individual. To minimise, even more so to neglect, any one of these aspects leads almost always to failure.

In order to take this into account, as well as to $\vec{V}$ interpret the messages which are sometimes sent, over is and above words, by unspeakable pain, and in order to find effective responses to these appeals for aid, the $\frac{\partial}{\mathrm{T}}$ best instrument has proved to be a multidisciplinary $\infty$ team working in a warm, cheerful and welcoming 의 therapeutic environment.

AVRE's staff thus includes general medical practitioners, psychiatrists, psychotherapists and physical therapists, as well as persons equipped to assist in acclimatising patients to their new social environment, for example by helping them to obtain housing, to meet often complicated administratios requirements and to learn the French language.

A very important task carried out by the associatio t is that of providing the facts and medical evidence which may be necessary to support applications for the granting of refugee status.

Although the care of torture victims is not a specialty $\stackrel{\mathbb{Q}}{\Omega}$ in itself, the co-ordinated work of AVRE's $\overrightarrow{\overrightarrow{0}}$ interdisciplinary staff does represent a holistic approach - implemented in accordance with varying individual needs - to the treatment of the multiple wounds left by the torture experience.

To understand and attempt to heal torture-induced traumas requires empathy, imagination and the tireless expenditure of time. It may also frequently involve the interpretation of behaviour having its roots in a culture alien to that of the therapist; what is considered 'normal' in one society may be regarded as 'abnormal' 웅 in another. It must nevertheless be noted that, in cases of extreme distress, patients give expression to their torment in the same ways, regardless of the cultural $N$ differences which separate them.

A grim particularity of torture is that it tortures for $\mathbb{N}$ a long time. Hence, the need for AVRE to keep abreast $\underset{\omega}{\widetilde{W}}$ of its patients' progress by encouraging them to return $\bar{\sigma}$ periodically for informal, relaxed conversation with 0 the staff - or, where necessary, for a more systematic $\mathbb{D}$ pursuit of specific medical or psychological care. The $\stackrel{\odot}{+}$ deep incursions which torture makes into the living 0 substance of its victims do not permit the luxury of therapeutic short cuts.

Hélène Faffe, MD, is Head of AVRE, Paris, France. 